\title{
Succession and the Relationship between Vegetation and Soil in the Marl Quarries of the Yucatan Peninsula, Mexico
}

\author{
Mirna Valdez-Hernández ${ }^{1}$, Rossana Gil-Medina ${ }^{1}{ }^{\circledR}$, Jorge O. López-Martínez ${ }^{1,2, *}$, \\ Nuria Torrescano-Valle ${ }^{1}\left(\mathbb{D}\right.$, Nancy Cabanillas-Terán ${ }^{1,2}$ (D) and Gerald A. Islebe ${ }^{1}$ (D) \\ 1 El Colegio de la Frontera Sur, Avenida Centenario km 5.5, Quintana Roo, Chetumal 77014, Mexico; \\ mavaldez@ecosur.mx (M.V.-H.); rossd8@gmail.com (R.G.-M.); ntorresca@ecosur.mx (N.T.-V.); \\ ncabanillas@ecosur.mx (N.C.-T.); gislebe@ecosur.mx (G.A.I.) \\ 2 Conacyt-El Colegio de la Frontera Sur, Avenida Centenario km 5.5, Quintana Roo, Chetumal 77014, Mexico \\ * Correspondence: jorgelopez@ecosur.mx; Tel.: +52-999-127-54-02
}

Received: 5 December 2018; Accepted: 29 January 2019; Published: 1 February 2019

\begin{abstract}
Open-pit mining is a common activity in the Yucatan Peninsula for the extraction of limestone. These areas are characterized by the total removal of the natural vegetation cover and soil in order to access calcareous material. The present study shows the composition and structure of the vegetation in five quarries after approximately ten years of abandonment, and the target vegetation near to the quarries in southeastern Mexico. A linear mixed model showed that $\mathrm{P}$ availability is one of the limiting factors for species establishment in the quarries. Using a canonical correspondence analysis (CCA), the distribution of the species was determined in relation to the edaphic variables: soil depth, the percentage of organic matter (OM), cationic exchange capacity (CEC), $\mathrm{pH}$ and texture. Twenty-six families, 46 genera and 50 species were recorded in the quarries, and 25 families, 45 genera and 47 species were recorded in the conserved areas. The dominant species in the quarries belong to the families Poaceae, Fabaceae, Rubiaceae and Anacardiaceae. The quarries with higher values of OM $(2 \%)$, CEC $(24 \mathrm{Cmol} / \mathrm{kg})$, depth $(11 \mathrm{~cm})$ and sand percentage $(31 \%)$ include the following species Lysiloma latisiliquum (L.) Benth., Metopium brownei (Jacq.) Urb. and Bursera simaruba (L.) Sarg., which are common in secondary forests. Quarries with lower values of OM $(0.4 \%)$, CEC $(17 \mathrm{Cmol} / \mathrm{kg})$ and depth (5.02), and with a higher percentage of silt (42\%) were dominated by herbs belonging to Poaceae and by Borreria verticillate (L.) G. Mey., which are typical in disturbed areas of southeastern Mexico. In all cases, the $\mathrm{pH}$ was slightly alkaline due to the content of calcium carbonate $\left(\mathrm{CaCO}_{3}\right)$, characteristic of the soils of the region.
\end{abstract}

Keywords: Post-mining regeneration; limestone quarry; tropical dry forest; quarry recovery

\section{Introduction}

Open-pit mining for the extraction of mineral resources is one of the most severe anthropogenic disturbances affecting forests, involving the removal of the vegetation and modification of soil horizons and structures, which may have significant effects on ecosystem processes. Globally, mining extraction has been determined to cover about $1 \%$ of the earth's surface. To restore areas degraded by mining, it is important to compare mined areas to neighboring areas that have not been excavated $[1,2]$. There are few studies that evaluate the rate and characteristics of natural regeneration after mining in southeastern Mexico. However, in other parts of the world, detailed studies on vegetation restoration are available [3-5]. In the Yucatan Peninsula, open-pit mining is used to extract marl and marlstones. In the state of Quintana Roo, where infrastructure development has occurred rapidly over the past few decades, official statistics describe current and abandoned marl and marlstone quarries as occupying 
$7.94 \mathrm{~km}^{2}$ of the $44,566 \mathrm{~km}$ of the state $(0.02 \%)$. It seems likely that this is an underestimate. This study was carried out to determine the floristic composition, diversity and structure of vegetation in abandoned quarries in Quintana Roo, as compared to neighboring target vegetation, and to understand how these vary with soil variables, with the objective of providing insights relevant to the restoration of these degraded areas. Dominant vegetation near the marl quarries consists of seasonally dry tropical forest with species of Fabaceae as most conspicuous canopy trees. The seasonal dry tropical forests of the Yucatan Peninsula are adapted to severe natural disturbances like hurricanes and fire [6,7]. Traditional agricultural practices have shaped the landscape for centuries [8].

\section{Materials and Methods}

\subsection{Study Area}

The study was carried out near Xul-Ha, municipality of Othon P. Blanco, in the southeastern part of the state of Quintana Roo (Figure 1). The predominant vegetation is seasonal dry tropical forest [9]. However, it is common to find areas in different states of secondary succession known as acahuales, caused by different types of natural and anthropogenic disturbances [10]. According to the Köppen climatic classification, modified by García [11], the climate is warm subhumid with summer rain and a dry season between January and April. The average annual precipitation fluctuates between 1100 and $1200 \mathrm{~mm}$ [12], and the average annual temperature recorded in the last decade is $26.5^{\circ} \mathrm{C}$ [13]. The type of soil is rich in calcium carbonates $\left(\mathrm{CaCO}_{3}\right)$, and the most common is rendzic Leptosol, followed by Vertisols, Luvisols and Gleysols, which are distributed in patches in the study area [14].

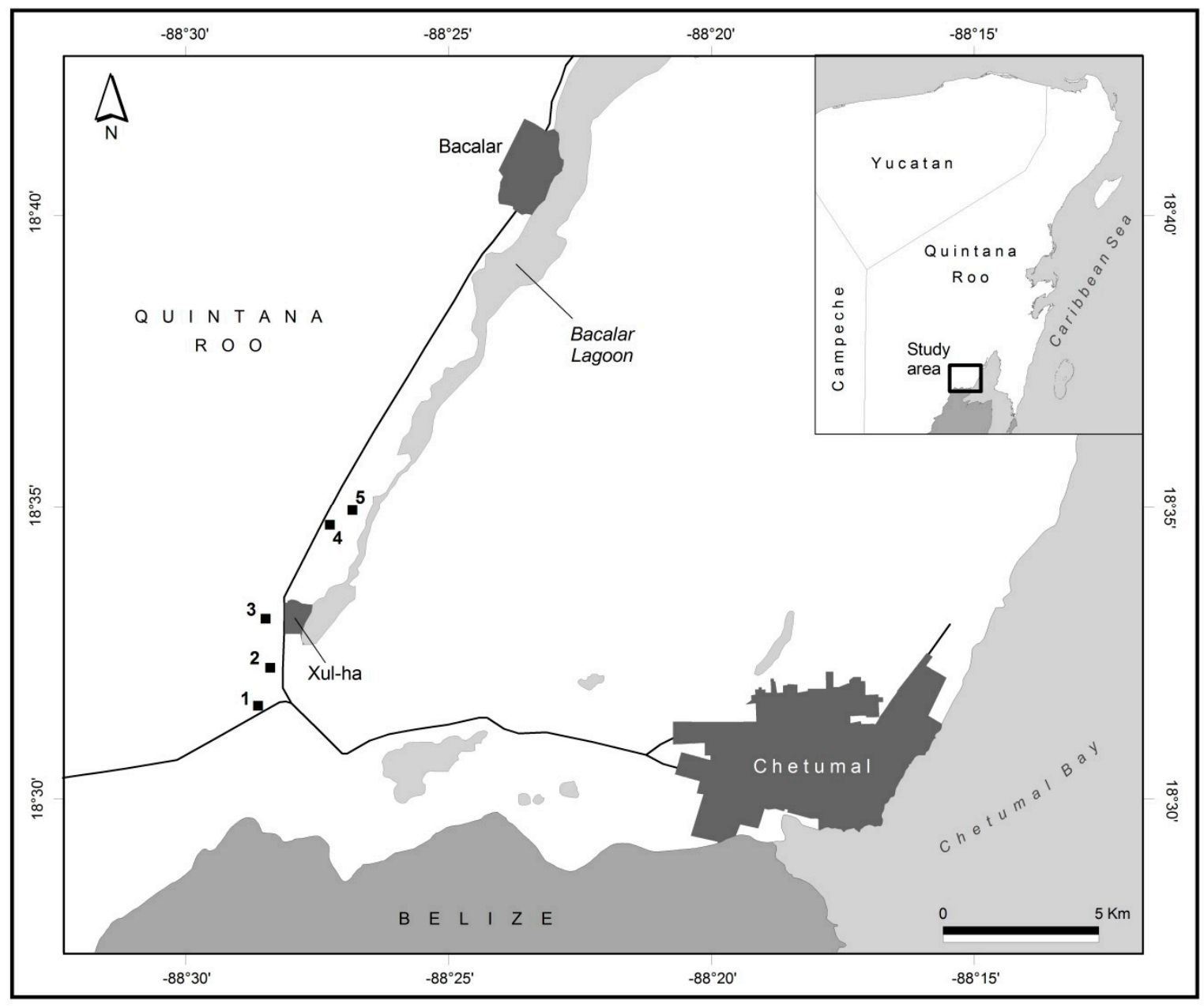

Figure 1. The location of the study area and of the sampled quarries. 


\subsection{Sampling Design}

Five marl quarries were selected for the purpose of our study. Two selection criteria were established: (i) at least ten years of abandonment and (ii) that they were embedded in a matrix of vegetation or forest remnants, after here considered as target vegetation, and at a distance of no more than $100 \mathrm{~m}$ (Table 1). The time of abandonment of the quarries was determined based on interviews with the owners and authorities of the region. The distance between the quarries varied between $0.78-1.55 \mathrm{~km}$. The target vegetation [15] was selected based on the structure of the vegetation, with a relatively closed canopy and a height of $10 \mathrm{~m}$ or more.

Table 1. The stand information of the five studied quarries. The approximate time of abandonment is presented in years. $\mathrm{L}=$ Leptosol; $\mathrm{R}=$ Rendzina.

\begin{tabular}{ccrccc}
\hline Quarry & Age (Years) & Coordinates & Soil & Soil Depth & Quarry Depth \\
\hline \multirow{2}{*}{1} & 10 & $\begin{array}{r}18^{\circ} 31^{\prime} 30.5^{\prime \prime} \mathrm{N} \\
-88^{\circ} 28^{\prime} 29.5^{\prime \prime} \mathrm{W}\end{array}$ & L, R & $7 \mathrm{~cm}$ & $3-6 \mathrm{~m}$ \\
2 & 10 & $\begin{array}{r}18^{\circ} 32^{\prime} 10.1^{\prime \prime} \mathrm{N} \\
-88^{\circ} 28^{\prime} 16.3^{\prime \prime} \mathrm{W}\end{array}$ & L, R & $5 \mathrm{~cm}$ & $3-6 \mathrm{~m}$ \\
3 & 10 & $\begin{array}{r}18^{\circ} 33^{\prime} 01.1^{\prime \prime} \mathrm{N} \\
-88^{\circ} 28^{\prime} 21.9^{\prime \prime} \mathrm{W}\end{array}$ & L, R & $8 \mathrm{~cm}$ & $6 \mathrm{~m}$ \\
& 10 & $\begin{array}{r}18^{\circ} 34^{\prime} 39.6^{\prime \prime} \mathrm{N} \\
-88^{\circ} 27^{\prime} 12.8^{\prime \prime} \mathrm{W}\end{array}$ & L, R & $11 \mathrm{~cm}$ & $1-3 \mathrm{~m}$ \\
4 & 10 & $\begin{array}{r}18^{\circ} 34^{\prime} 55.0^{\prime \prime} \mathrm{N} \\
-88^{\circ} 26^{\prime} 48.1^{\prime \prime} \mathrm{W}\end{array}$ & L, R & $10 \mathrm{~cm}$ & $1-3 \mathrm{~m}$ \\
\hline
\end{tabular}

\subsection{Vegetation Sampling}

In each quarry, 12 randomly distributed quadrants of $10 \times 10 \mathrm{~m}\left(100 \mathrm{~m}^{2}\right)$ were sampled. Additionally, three target plots of $10 \times 10\left(100 \mathrm{~m}^{2}\right)$ were established in surrounding conserved areas. In each plot, tree layer species were identified and of all individuals, the diameter at breast height $(\mathrm{DBH}) \geq 1 \mathrm{~cm}$ was recorded. For the herb layer (height $<1 \mathrm{~m}$ ), four subplots of $1 \times 1 \mathrm{~m}\left(1 \mathrm{~m}^{2}\right)$ were randomly established within each plot of $100 \mathrm{~m}^{2}$. In all plots species, the abundance, height and diameter at breast height (DAP) were recorded. We recorded growth forms in the following categories: trees, shrubs, herbs, palms, epiphytes, ferns and lianas.

\subsection{Soil Sampling}

Four soil samples per quarry and target vegetation were taken with a soil corer at a $10 \mathrm{~cm}$ depth. The four soil samples were mixed, giving one composite sample (500 g) per quarry and target vegetation. Composite samples were analyzed following the Norma Oficial Mexicana NOM-021-RECNAT-2000. The following components were determined: Total nitrogen (Nt, Micro Kjeldahl method), Phosphorus (Olsen method), Potassium (K, AS-12 with ammonium acetate), $\mathrm{pH}$ (water 2: 1), organic matter (MO, Walkley and Black method), cation exchange capacity (CIC, ammonium acetate $\mathrm{pH} 7.0$ ), and texture (Boucoucos method).

\subsection{Data Analysis}

To compare the taxonomic diversity of the treatments, a rarefaction analysis (interpolation) and extrapolation (prediction) of the Hill numbers were performed, based on sample size and coverage, which represents a unified criterion to contrast the diversity of multiple assemblages [16]. The analysis was carried out based on the order $\mathrm{q}$ (richness of species) and richness estimators were determined with the iNEXT software package $\mathrm{R}$. The relative importance value index was calculated for each quarry, and for the functional groups IVI = relative density + relative area basal + relative frequency. Where: relative density $=(\text { number of individuals of species } / \text { total number of individuals })^{*} 100$; relative 
basal area $=(\text { basal area of a species } / \text { basal area of all species })^{*} 100$; relative frequency $=($ frequency of a species/frequency of all species)*100 [17].

An unimodal-based approach (CCA) was used after calculating gradient length with DCA, which exceeded 3 SD [18]. The abundance was established with a transformation of Hellinger, which minimizes the weight of rare species. The analysis was carried out with the CANOCO 4.56 package [19].

To evaluate the importance of the site on the relationship between soil variables and vegetation variables, richness and abundance were used to calculate a mixed linear model (LMM), from the nlme package for $\mathrm{R}$ developed by Laird and Ware [20]. Soil variables were established as fixed factors and sites as random variables.

\section{Results}

\subsection{Floristic Composition}

We recorded 8372 individuals, belonging to 37 families, 71 genera and 77 species. The species can be distributed in three growth forms: trees, herbs and lianas (Table 2). The family with the highest species richness was Poaceae with 10 species, followed by Fabaceae with 8 species, Euphorbiaceae with 5 species, and Rubiaceae and Sapotaceae with 4 species. Those families contributed $31 \%$ of all botanical families. The remaining $69 \%$ was distributed among 28 families, 7 with two species and 21 with one species. Within the trees, the most important families were Fabaceae with 8 species, Sapotaceae with 4 and Anacardiaceae with 3, followed by Arecaceae and Euphorbiaceae. The rest of the families (15) were represented by a single species. In the herb layer, the most important families were Poaceae with 10 species, Asteraceae and Euphorbiaceae with 3 species, and Cyperaceae and Rubiaceae with 2. The 12 remaining species were represented by a single species. Lianas were represented by five families, Convolvulaceae with 2 species and Apocynaceae, Bignoniaceae, Passifloraceae, Rubiaceae with 1 species (Table 2).

Quarry 5 had the most species with 45 species, followed by quarry 3 with 37 species. Quarries 2 and 1 had 36 and 35 species and Quarry 4 had the lowest species richness with 34 . Trees represented $52 \%$ of the total species sampled with 40 species, followed by herbs and lianas that represented 41 and $8 \%$ with 32 and 6 species, respectively (Table 2). The highest abundance was recorded in the quarry 2 (2505 individuals), followed by 5 (1722 individuals), 4 (1378 individuals) and 3 and 1 (874 and 870 individuals, respectively). Herbs were the most abundant growth form with 7045 individuals, representing $84 \%$ of the total abundance. Quarries 2 and 5 had the highest proportion of herb abundance, representing $58 \%$ of the total (2513 and 1540 individuals, respectively). The trees represented $14 \%$ of the total abundance of the community, being more abundant in the quarries 5 and 4 (378 and 359 individuals, respectively). Finally, the lianas were the least abundant with 171 individuals distributed as follows: 5 (52), 3 (51), 2 (27), 4 (22) and 1 (19). Higher species richness was observed in the quarries (50) than in the target vegetation (47). The difference is statistically significant because the intervals do not overlap (Table 3). The species richness of the trees was higher in the target vegetation (34) than in the quarries (19). Herbs presented a higher richness of species in the quarries than in the target vegetation. Lianas did not show significant differences (Table 3). 
Table 2. The list of species sampled in all quarries and target vegetation, indicating their growth form (GF, $\mathrm{T}=$ tree, $\mathrm{H}=$ herb, $\mathrm{F}=$ fern, $\mathrm{E}=$ epiphyte, $\mathrm{S}=$ shrub, $\mathrm{P}=$ palm; $\mathrm{L}=$ liana). $1-5=$ marl quarries; $\mathrm{T}=$ target vegetation.

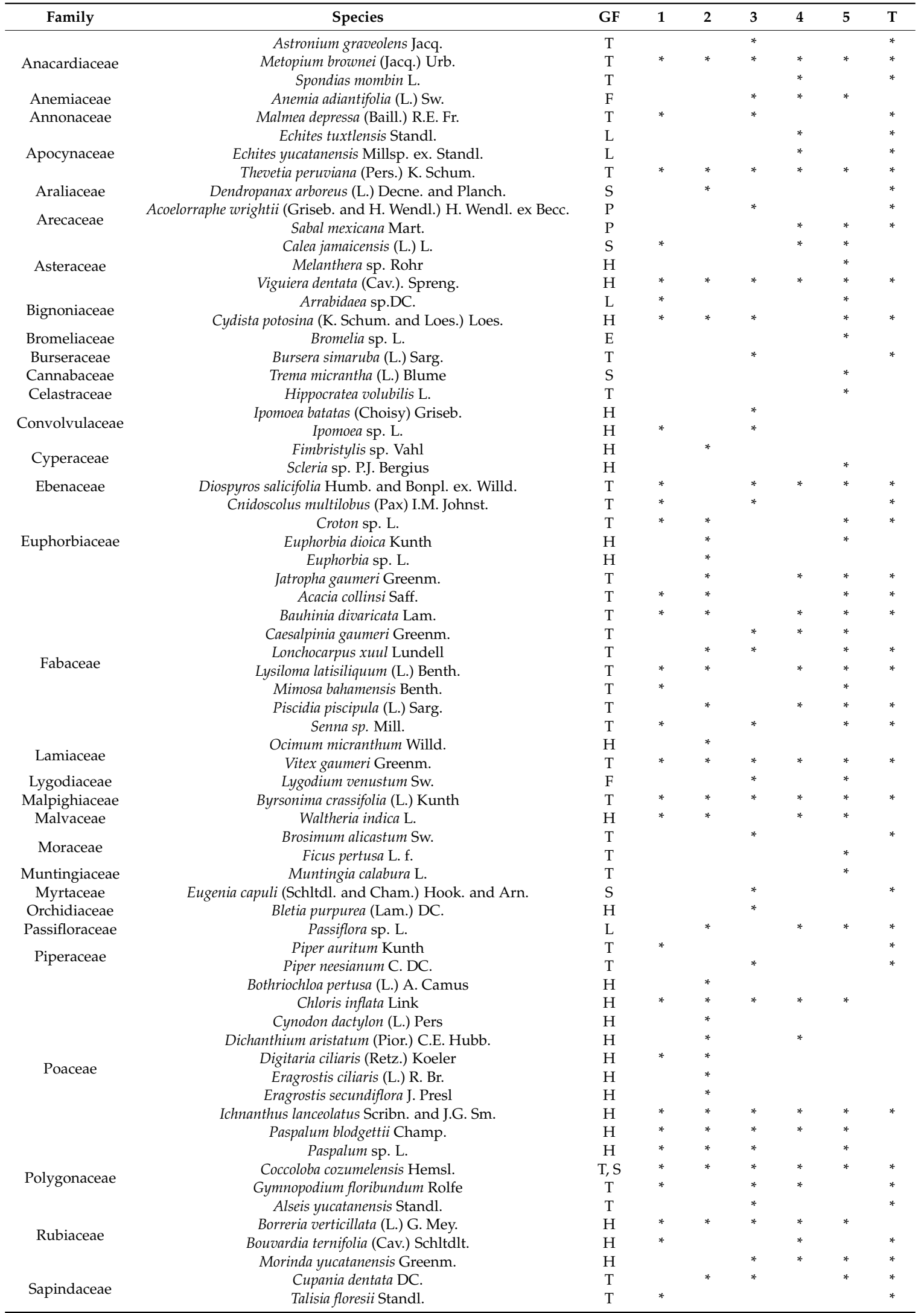


Table 2. Cont.

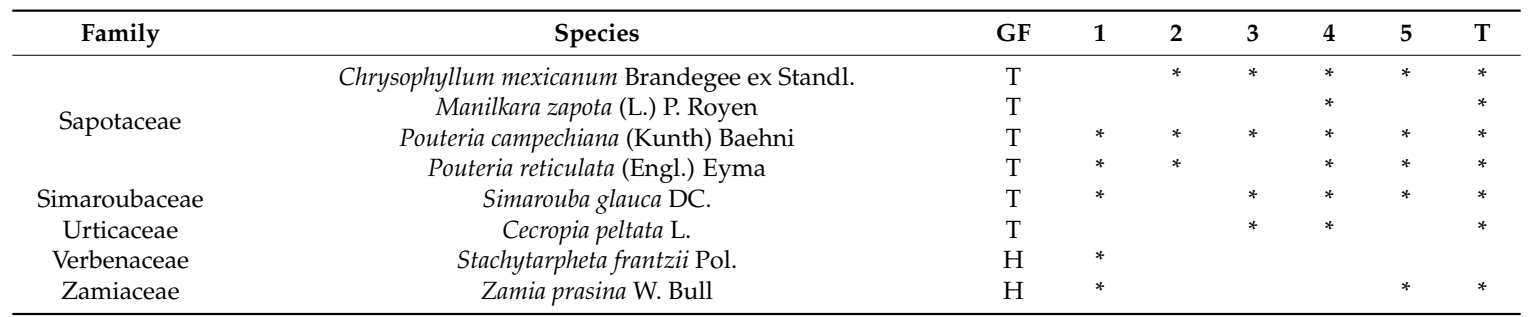

Table 3. The growth form diversity estimates of the studied quarries and target vegetation.

\begin{tabular}{|c|c|c|c|c|c|c|c|c|c|c|}
\hline & Growth form & $n$ & S. obs & m & qD & qD.LCL & qD.UCL & SC & SC.LCL & SC.UCL \\
\hline Target forest & & 1023 & 47 & 1023 & 47 & 44.1 & 49.9 & 1 & 0.99 & 1 \\
\hline \multirow[t]{3}{*}{ Quarry } & Herbs & 6842 & 27 & 68 & 11.64 & 11.35 & 11.92 & 0.93 & 0.93 & 0.94 \\
\hline & Lianas & 70 & 5 & 68 & 5 & 3.57 & 6.43 & 0.99 & 0.96 & 1 \\
\hline & Trees & 719 & 34 & 80 & 21.82 & 20.7 & 22.93 & 0.91 & 0.9 & 0.92 \\
\hline
\end{tabular}

$n=$ number of individuals, S.obs $=$ number of recorded species, $\mathrm{m}=$ sample size for which diversity estimates of order $\mathrm{q}$ was compared, $\mathrm{qD}=$ the estimated diversity of order $\mathrm{q}$ for a sample of size $\mathrm{m}, \mathrm{SC}=$ the estimated sample coverage for a sample of size m, qD.LCL, qD.UCL = the bootstrap lower and upper confidence limits for the diversity of order $\mathrm{q}$ at the specified level in the setting (with a default value of 0.95), SC.LCL, SC.UCL = the bootstrap lower and upper confidence limits for the expected sample coverage at the specified level in the setting (with a default value of 0.95 ).

\subsection{Vegetation Structure}

The herb layer in the quarries was represented mainly by species of the family Rubiaceae and Poaceae with the highest IVI values. Borreria verticillata was the dominant species in the quarries 1 , 2, 3 and 5, and E. ciliaris at 4 (Table 4). The herb layer of the target vegetation was dominated by the species Cydista potosina at T1, T2, T3 and T5. Viguiera dentata and Bouvardia ternifolia were the most dominant species of $\mathrm{T} 4$ [17].

The canopy layer of the quarries is dominated by Metopium brownei in quarry $1, A$. collinsii in 2 , Caesalpinia gaumeri in 3, Coccoloba cozumelensis with Lysiloma latisiliquum in 5, and L. latisiliquum in 4 (Table 4). The canopy layer of the target vegetation showed a wider distribution in the dominance of species, among which are L. latisiliquum, Vitex gaumeri, Alseis yucatanensis, Bursera simaruba, Pouteria campechiana, Diospyros salicifolia, among others (Table 4).

The structure of diametric classes in the quarries and in the target vegetation showed an inverted $j$ pattern, in which the largest number of individuals was concentrated in the youngest categories (Figure $2 \mathrm{~b}$ ). Of the 438 individuals measured in the quarries, $75 \%$ are in the first diametric class $(1-5 \mathrm{~cm})$, and decreases considerably in the second class $(5-10 \mathrm{~cm})$, including only $13 \%$ of the individuals; the other four categories had $13 \%$. Similar to the quarries, in the target vegetation, the individuals are concentrated in the smaller classes, grouping $84 \%$ of the individuals in the first two classes; while $17 \%$ was distributed in the four largest classes.

Species richness is mainly determined by phosphorus $(\mathrm{P})$, and is found in higher concentrations in soils of target vegetation (Table 5, Linear mixed model). CEC also determined species using LMM, and both variables were positively related. Species abundance within sites was only significant with $P$ (LMM, Table 5). 
Table 4. The Importance Value Index (IVI) in the quarries and target vegetation.

\begin{tabular}{|c|c|c|c|c|c|c|c|c|c|c|}
\hline \multirow[b]{2}{*}{ Herb layer } & \multicolumn{5}{|c|}{ Quarry } & \multicolumn{5}{|c|}{ Target Vegetation } \\
\hline & 1 & 2 & 3 & 4 & 5 & T1 & $\mathrm{T} 2$ & T3 & $\mathrm{T} 4$ & T5 \\
\hline Cydista potosina & - & - & - & - & - & 146 & 180 & 216 & - & 110 \\
\hline Borreria verticillata & 108 & 118 & 117 & 41 & 143 & - & - & - & - & - \\
\hline Ichnanthus lanceolatus & - & - & - & - & - & 58 & 75 & 45 & 75 & 79 \\
\hline Eragrostis secundiflora & - & 47 & 42 & 109 & - & - & - & - & - & - \\
\hline Paspalum blodgettii & 35 & 39 & - & 44 & 47 & - & - & - & - & - \\
\hline Paspalum sp. & 47 & 17 & 72 & - & - & - & - & - & - & - \\
\hline Arrabidaea sp. & - & - & - & - & - & 62 & - & - & - & 42 \\
\hline Viguiera dentata & - & - & - & - & - & - & - & - & 79 & - \\
\hline Morinda yucatanensis & - & - & 22 & - & 13 & - & - & - & - & 43 \\
\hline Bouvardia ternifolia & - & - & - & - & - & - & - & - & 76 & - \\
\hline Chloris inflata & - & - & - & 24 & 50 & - & - & - & - & - \\
\hline Digitaria ciliaris & 49 & - & - & - & - & - & - & - & - & - \\
\hline Passiflora sp. & - & - & - & - & - & - & 22 & - & 22 & - \\
\hline Cnidoscolus multilobus & - & - & - & - & - & - & - & 39 & - & - \\
\hline Dendropanax arboreus & - & - & - & - & - & - & 22 & - & - & - \\
\hline Zamia prasina & - & - & - & - & - & 21 & - & - & - & - \\
\hline Tree layer & 1 & 2 & 3 & 4 & 5 & T1 & T2 & T3 & $\mathrm{T} 4$ & T5 \\
\hline Lysiloma latisiliquum & - & - & - & 143 & 122 & 61 & 101 & - & 83 & - \\
\hline Metopium brownei & 193 & - & 64 & 64 & 23 & - & - & - & 38 & - \\
\hline Acacia collinsi & - & 300 & - & - & - & - & - & - & - & - \\
\hline Caesalpinia gaumeri & - & - & 189 & - & - & - & - & - & - & - \\
\hline Vitex gaumeri & - & - & - & 25 & - & - & 44 & 52 & - & 58 \\
\hline Coccoloba cozumelensis & - & - & 23 & - & 59 & - & - & - & - & 47 \\
\hline Bursera simaruba & 34 & - & - & - & - & 40 & 17 & - & 23 & - \\
\hline Byrsonima crassifolia & 39 & - & 24 & 18 & - & - & - & - & - & - \\
\hline Pouteria reticulata & - & - & - & - & - & 34 & - & - & 24 & - \\
\hline Alseis yucatanensis & - & - & - & - & - & - & - & 48 & - & - \\
\hline Croton reflexifoluis & - & - & - & - & - & - & 19 & - & - & 28 \\
\hline Mimosa bahamensis & 34 & - & - & - & 11 & - & - & - & - & - \\
\hline Pouteria campechiana & - & - & - & - & - & - & - & 45 & - & - \\
\hline Diospyros salicifolia & - & - & - & - & - & 41 & - & - & - & - \\
\hline Jatropha gaumeri & - & - & - & - & - & - & - & - & - & 25 \\
\hline Piper neesiariuum & - & - & - & - & - & - & - & 21 & - & - \\
\hline
\end{tabular}

The density was higher $(\mathrm{F}=6.0492, p=0.002)$ in the quarries $\left(31.7 \mathrm{ind} . / \mathrm{m}^{2} \pm 7.5\right)$ than in the target vegetation $(5.5$ ind. $/ \mathrm{m}^{2} \pm 2.5$, Figure 2a). Quarry 2 presented the highest value of density (54.16 ind. $/ \mathrm{m}^{2} \pm 9.3$ ), while quarries 1 and 3 obtained the lowest values (18.9 and 16.9 ind. $/ \mathrm{m}^{2}$ respectively). The target vegetation with the highest density was T4 with (14.2 ind. $\left./ \mathrm{m}^{2} \pm 8.9\right)$ and the lowest density was $\mathrm{T} 3\left(2.3 \mathrm{ind} . / \mathrm{m}^{2} \pm 0.8\right)$. 

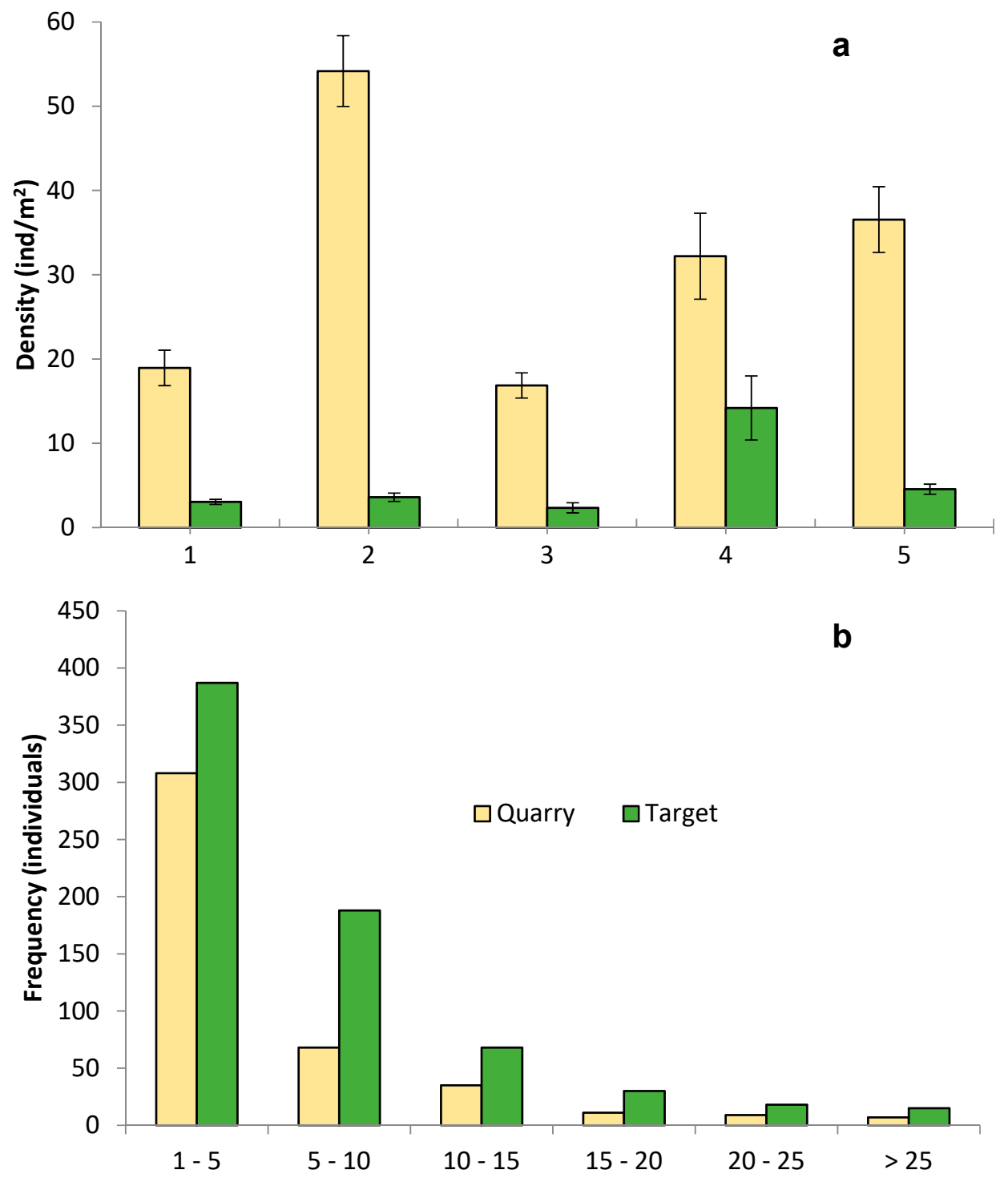

Figure 2. (a) The average density of individuals in each quarry and target vegetation. (b) Distribution in diametric classes of quarries $(n=438)$ and target vegetation $(n=706)$.

Table 5. The results of the linear mixed model (LMM), relating species richness and abundance with soil variables $\left.{ }^{*}=p<0.05\right)$.

\begin{tabular}{ccccccc}
\hline & Soil Variables & Value & Std.Error & DF & $t$-value & $p$-value \\
\hline \multirow{5}{*}{ Richness } & $\mathrm{P}$ & 2.16146 & 0.59018 & 12 & 3.662346 & $0.0033^{*}$ \\
& $\mathrm{MO}$ & -1.07686 & 3.89338 & 12 & -0.276587 & 0.7868 \\
& $\mathrm{~N}$ & -2.75591 & 79.88714 & 12 & -0.034498 & 0.973 \\
& $\mathrm{~K}$ & -0.00476 & 0.00889 & 12 & -0.535487 & 0.6021 \\
& $\mathrm{CEC}$ & 0.53992 & 0.14274 & 12 & 3.782563 & $0.0026^{*}$ \\
& $\mathrm{pH}$ & 3.64087 & 3.36148 & 12 & 1.083114 & 0.3 \\
Abundance & $\mathrm{P}$ & 18.326 & 6.2714 & 12 & 2.9221351 & $0.0128^{*}$ \\
& $\mathrm{MO}$ & 16.6783 & 41.4912 & 12 & 0.4019714 & 0.6948 \\
& $\mathrm{~N}$ & -378.4637 & 851.7639 & 12 & -0.4443294 & 0.6647 \\
& $\mathrm{~K}$ & -0.0465 & 0.0945 & 12 & -0.4923956 & 0.6313 \\
& $\mathrm{CEC}$ & 2.5481 & 1.5194 & 12 & 1.6770404 & 0.1194 \\
& $\mathrm{pH}$ & 59.8267 & 35.8774 & 12 & 1.6675331 & 0.1213 \\
\hline
\end{tabular}


The canonical correspondence analysis (CCA) explained $60 \%$ of the total variance, with an eigenvalue of 0.89 for the first axis and 0.61 for the second axis, representing $36 \%$ and $25 \%$ of the total variance, respectively. The first axis is determined by the increase in the concentration of organic matter (OM), CEC, and percentage of sand. The second axis is determined by the increase in silt and $\mathrm{pH}$ (Figure 3). In Figure 3, the plots sampled in the quarries and target vegetation are presented. Most plots of the target vegetation (T1, T2, T3, T5) are grouped in the lower left; except for target vegetation 4 (T4) located in the upper left, which was characterized by showing the highest content of MO, nitrogen $(\mathrm{N})$, phosphorus $(\mathrm{P})$ and potassium $(\mathrm{K})$. Regarding the plots of the quarries, most of the plots $(1,2,3,5)$ are grouped in the central part of the biplot; except 4 , which presented better soil conditions given its distribution on axis 2. In general, it was observed that the quarries presented a soil with a slightly alkaline $\mathrm{pH}$, unlike the target vegetation with a neutral $\mathrm{pH}$ and a higher percentage of silt.

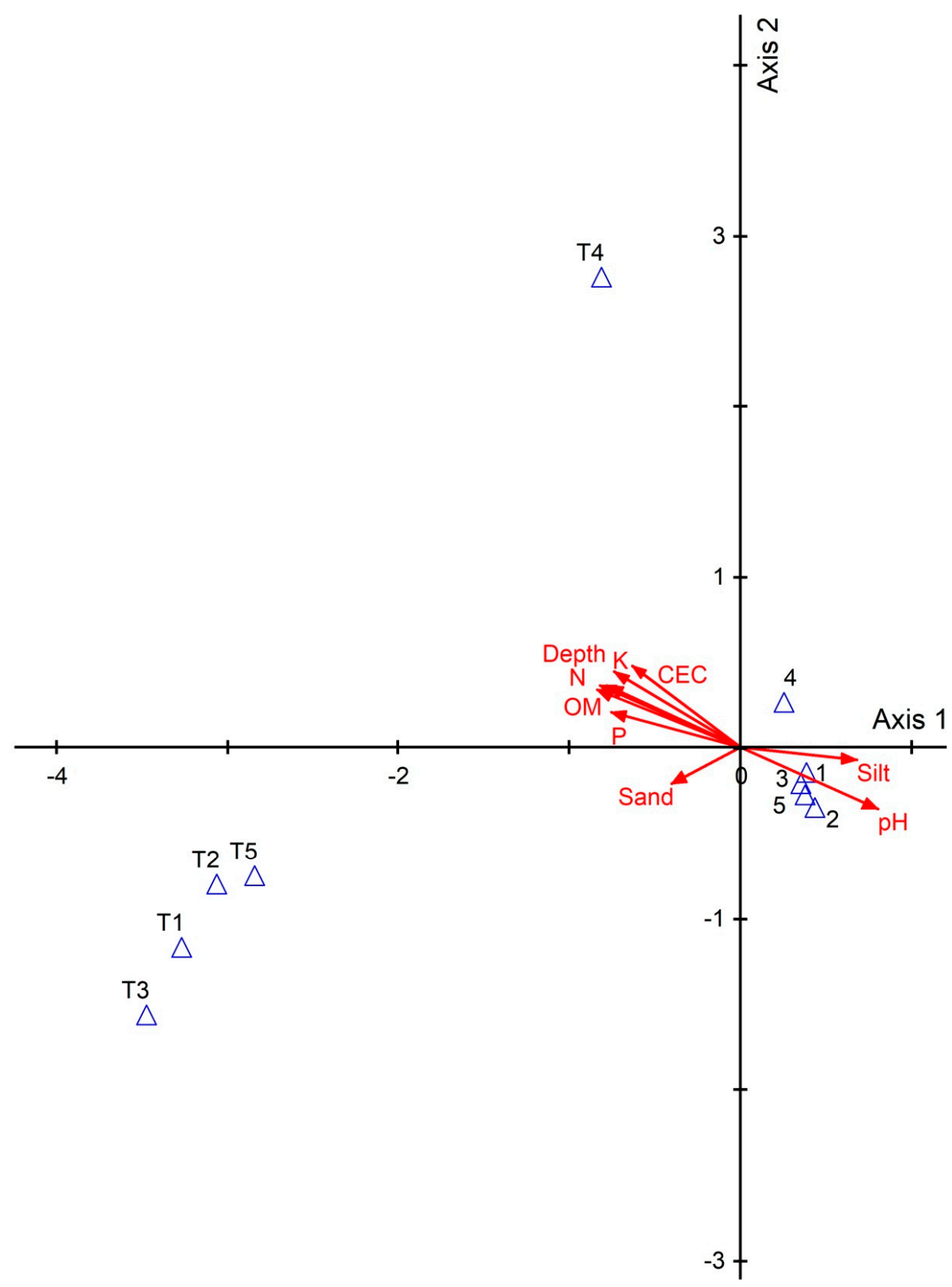

Figure 3. Canonical Correspondence Analysis (CCA) biplot of plots and soil variables. $\mathrm{T}=$ target vegetation, 1-5 quarries. Depth refers to the soil depths of plots, $\mathrm{OM}=$ organic material, $\mathrm{N}=$ nitrogen, $\mathrm{P}=$ phosphorus, $\mathrm{K}=$ potassium, $\mathrm{CEC}=$ cation exchange capacity. 


\section{Discussion}

Marl quarries and target vegetation presented a similar number of species (50 and 47, respectively), but a different composition. In the herb layer of the quarries, the species belonging to Poaceae, Asteraceae and Rubiaceae, were those that presented higher density. Poaceae, Rubiaceae and Fabaceae, presented the highest values of IVI in the quarries, which are characterized by presenting species capable of establishing themselves in areas of early regeneration. This has also been observed in other regions [21]. Those families have been reported in the early stages of succession of the region [22], and are being common in areas that have suffered some levels of disturbance.

Dominant tree species of the quarries and target vegetation are L. latisiliquum, M. brownei, Byrsonima crassifolia. Those species are characteristic of the secondary forests of the region $[10,22]$ and establish mainly by seeds after hurricanes, fires and traditional agricultural activities. Generally, those species can develop both in shallow soils, typical of quarries, and deep soils with good drainage [23]. In contrast, the conserved areas showed a dominance of species such as L. latisiliquum, V. gaumeri, C. cozumelensis, M. brownei, P. piscipula, Piper auritum, P. neesianum, Croton reflexifoluis, Spondias mombin, $P$. campechiana, which have been identified as species with relatively high dominance values, and are present in different successional conditions of dry tropical forests [24,25] of southeastern Mexico. Most of those tree species present re-sprouting in contrast to L. latisiliquum and therefore appear earlier.

Growth forms showed clear differences between the quarries and the target vegetation (Table 3). Trees showed the greatest species richness in the target vegetation, contrary to herbs that clearly dominated the quarry areas. This clearly agrees with that reported in previous studies in tropical forests [26-28]. Finally, lianas did not show significant differences between the target vegetation and the quarries (4 and 5, respectively, Table 3). However, the abundance was higher in the target vegetation. This may be related to the availability of larger trees in the target vegetation, which offer more availability of structural support $[26,29]$ contrary to the vegetation structure of the degraded sites.

The high number of individuals in smaller diameter classes, present in the quarries, indicate the juveniles individuals in a successional state of less than 15 years [30], as $95 \%$ of the total individuals do not exceed $15 \mathrm{~cm}$ of DAP (Figure $2 \mathrm{~b}$ ). The species that presented the highest number of individuals in the five diametric classes were L. latisiliquum and M. brownei, which are found mainly in quarries 4 and 5 , supporting the evidence that these quarries are in an advanced successional state compared to the other quarries. In addition, the presence of these deciduous species probably helps the accumulation of $\mathrm{MO}$ and hence, to an improvement of edaphic conditions.

Based on the results of the CCA, species groups present in the target vegetation and the species present in the quarries can be identified (Figure 3). The quarry species are characterized by species of early successional stages, which decrease as the process of succession progresses and are replaced by species of late succession [31]. The species present in the target vegetation are grouped on the right side of the graph, where the depth of the soil is greater than in the quarries, favoring the accumulation of organic matter. Some of the species present in these areas, such as B. simaruba and Byrsonima crassifolia are deciduous, which promote the constant accumulation of organic matter. Likewise, the species that are colonizing part of the marl quarries such as L. latisiliquum, M. brownei and B. simaruba, are located between the group of species from the quarries and those of the target vegetation, which shows that these species are capable of developing both in shallow soils and in deeper soils [23].

In the ordination graph (Figure 3), the sample plots of quarry 4 are distributed towards the right side of the graph, where the values of soil properties approximate those of the conserved areas. The conditions of the substrate clearly affect the distribution and abundance of the species [24].

The variation of silt and sand in the quarries and target vegetation, indicates that, at higher levels of silt, the successional process develops slowly. Soils with high percentages of silt have a lower drainage than sandy soils [32]. This may lead to partially flooding, during the wet season, and favors formation of superficial crusts that prevent the emergence of tree seedlings [33]. The LMM identified $\mathrm{P}$ as a significant limiting factor in vegetation recovery in the quarries (Table 5). From previous studies of dry tropical forests of the Yucatan Peninsula, P was known as limiting factor of forest 
regeneration $[34,35]$. Establishment of tree seedlings was also driven by P availability [34], hence the complete removal of the soils regulates tree seedling colonization in the quarries.

This work shows the high tolerance to stress conditions of certain species such as Paspalum sp., Eragrostis secundiflora, Chloris inflata, Borreria verticillata, Calea jamaicensis, Metopium brownei, Caesalpinia gaumeri and Lysiloma latisiliquum, being the most dominant in the quarries. It shows the slow recovery of vegetation, explained by the total loss of soil. The effect of total soil removal, the consequent edaphic conditions that occur in the quarries, such as a slightly alkaline $\mathrm{pH}$, lower percentage of $\mathrm{OM}$, lower $\mathrm{CIC}$, higher percentage of silt and lower percentage of sand, are ecologically significant, as they present a clear correlation with the distribution of the species, and with the characteristics of the structure of the vegetation.

\section{Conclusions}

One of the main consequences of marl quarries in the Yucatan Peninsula is the total loss of soil, modifying edaphic conditions and, therefore creating unfavorable conditions for species to recolonize areas formerly covered by dry tropical forest. Common species in marl quarries are Borreria verticillata and Eragrostis secundiflora. These species develop in soils with a high percentage of silt and with a slightly alkaline $\mathrm{pH}$, unlike the typical species of dry forests, which grow on soils with an acidic $\mathrm{pH}$ and a higher percentage of sand. A linear mixed model showed that $\mathrm{P}$ availability is one of the limiting factors for species establishment in the quarries.

The quarries were dominated by herbs. However, there are some tree species that have a wide range of tolerance to different edaphic conditions, such as Lysiloma latisiliquum and Metopium brownei, and both can be found in quarries and surrounding dry tropical forests.

Although the diversity values obtained in the quarries and the target vegetation are not statistically significant, a higher complexity can be observed in the target vegetation. These differences in the development and distribution of the species, as well as in the structure of the plant communities of the quarries and the target vegetation are strongly correlated with the edaphic conditions. Studies from Central Europe [5] have concluded that spontaneous vegetation succession is adequate for ecosystem restoration. Our study supports this view, if nearby natural vegetation remnants are available, spontaneous vegetation recovery is possible.

Under this view, it is important to carry out studies focused on the successional development in the quarries of the Yucatan Peninsula in order to have a better understanding of the response of the species to this type of disturbances. With this information, it will be possible to apply adequate management plans, restoration and conservation of these areas.

Author Contributions: Conceptualization, M.V.-H. and G.A.I.; Formal analysis, M.V.-H., R.G.-M., J.O.L.-M. and G.A.I.; Methodology, R.G.-M.; Writing—original draft, M.V.-H., R.G.-M., J.O.L.-M. and G.A.I.; Writing一review \& editing, N.T.-V. and N.C.-T.

Funding: Conacyt funded RGM under grant number 573900.

Acknowledgments: Juan Javier Ortiz Díaz is acknowledged for taxonomic identification of Poaceae. Oscar Verduzco Salazar, Jorge Palomo Kumul and Holger Weissenberger are acknowledged for help during fieldwork. Holger Weissenberger elaborated Figure 1.

Conflicts of Interest: The authors declare no conflict of interest.

\section{References}

1. Baasch, A.; Kirmer, A.; Tischew, S. Nine years of vegetation development in a postmining site: Effects of spontaneous and assisted site recovery. J. Appl. Ecol. 2011, 49, 251-260. [CrossRef]

2. Kirmer, A.; Tischew, S.; Ozinga, W.A.; von Lampe, M.; Baasch, A.; van Groenendael, J.M. Importance of regional species pools and functional traits in colonization processes: Predicting re-colonization after large-scale destruction of ecosystems. J. Appl. Ecol. 2008, 45, 1523-1530. [CrossRef]

3. Boscutti, F.; Vianello, A.; Bozzato, F.; Casolo, V. Vegetation structure, species life span, and exotic status elucidate plant succession in a limestone quarry reclamation. Restor. Ecol. 2017, 25, 595-604. [CrossRef] 
4. Prach, K.; Hobbs, R.J. Spontaneous Succession versus Technical Reclamation in the Restoration of Disturbed Sites. Restor. Ecol. 2008, 16, 363-366. [CrossRef]

5. Prach, K.; Řehounková, K.; Lencová, K.; Jírová, A.; Konvalinková, P.; Mudrák, O.; Študent, V.; Vaněček, Z.; Tichý, L.; Petřík, P.; et al. Vegetation succession in restoration of disturbed sites in Central Europe: The direction of succession and species richness across 19 seres. Appl. Veg. Sci. 2014, 17, 193-200. [CrossRef]

6. Sanchez, O.; Islebe, G. Hurricane Gilbert and structure changes in a tropical forest in south-eastern Mexico. Glob. Ecol. Biogeogr. 1999, 8, 29-38. [CrossRef]

7. Whigham, D.F.; Olmsted, I.; Cano, E.C.; Harmon, M.E. The Impact of Hurricane Gilbert on Trees, Litterfall, and Woody Debris in a Dry Tropical Forest in the Northeastern Yucatan Peninsula. Biotropica 1991, 23, 434-441. [CrossRef]

8. Islebe, G.A.; Sánchez-Sánchez, O.; Valdéz-Hernández, M.; Weissenberger, H. Distribution of Vegetation Types. In Biodiversity and Conservation of the Yucatán Peninsula; Islebe, G.A., Calmé, S., León-Cortés, J.L., Schmook, B., Eds.; Springer International Publishing: Cham, Switzerland, 2015; pp. 39-53. ISBN 9783319065298.

9. Miranda, F.; Hernández-X, E. Los tipos de vegetación de México y su clasificación. Sociedad Botánica Méx 1963, 28, 29-179. [CrossRef]

10. Sánchez-Sánchez, O.; Islebe, G.A. Tropical forest communities in southeastern Mexico. Plant Ecol. 2002, 158, 183-200. [CrossRef]

11. García, E. Modificaciones al Sistema de Clasificación Climática de Köppen; Serie Libros; Instituto de Geografía, Universidad Nacional Autónoma de México: Mexico City, Mexico, 2004; Volume 6, ISBN 9789703210107.

12. Instituto Nacional de Estadística y Geografía (INEGI). Mapa digital de México V6.3.0. Available online: http:/ / www.beta.inegi.org.mx (accessed on 5 December 2018).

13. Espinoza-Ávalos, J.; Islebe, G.A.; Hernández-Arana, H.A. El sistema ecológico de la Bahía de Chetumal/Corozal: Costa occidental del Mar Caribe; El Colegio de la Frontera Sur: Chetumal, Mexico, 2009; ISBN 9786077637134.

14. Torrescano-Valle, N.; Folan, W.J. Physical Settings, Environmental History with an Outlook on Global Change. In Biodiversity and Conservation of the Yucatán Peninsula; Islebe, G.A., Calmé, S., León-Cortés, J.L., Schmook, B., Eds.; Springer International Publishing: Cham, Switzerland, 2015; pp. 9-37. ISBN 9783319065298.

15. Society for Ecological Restoration International Science \& Policy Working Group the SER International Primer on Ecological Restoration; Society for Ecological Restoration International: Tucson, AZ, USA, 2004.

16. Hsieh, T.C.; Ma, K.H.; Chao, A. iNEXT: An R package for rarefaction and extrapolation of species diversity (Hill numbers). Methods Ecol. Evol. 2016, 7, 1451-1456. [CrossRef]

17. Müller-Dombois, D.; Ellenberg, H. Aims and Methods of Vegetation Science; Wiley: New York, NY, USA, 1974.

18. ter Braak, C.J.F.; Smilauer, P. CANOCO Reference Manual and CanoDraw for Windows User's Guide: Software for Canonical Community Ordination (Version 4.5); Microcomputer Power: Ithaca, NY, USA, 2002.

19. Lepš, J.; Šmilauer, P. Using the CANOCO for Windows 4.5 package. In Multivariate Analysis of Ecological Data Using CANOCO; Cambridge University Press: Cambridge, UK, 2003; pp. 43-59.

20. Pinheiro, J.; Bates, D.; DebRoy, S.; Sarkar, D.; R Core Team. nlme: Linear and Nonlinear Mixed Effects. Available online: https:// cran.r-project.org/web/packages/nlme/citation.html (accessed on 5 December 2018).

21. Alday, J.G.; Pallavicini, Y.; Marrs, R.H.; Martínez-Ruiz, C. Functional groups and dispersal strategies as guides for predicting vegetation dynamics on reclaimed mines. Plant Ecol. 2011, 212, 1759-1775. [CrossRef]

22. Valdez-Hernández, M.; Sánchez, O.; Islebe, G.A.; Snook, L.K.; Negreros-Castillo, P. Recovery and early succession after experimental disturbance in a seasonally dry tropical forest in Mexico. For. Ecol. Manag. 2014, 334, 331-343. [CrossRef]

23. Pennington, T.D.; Sarukhán, J. Árboles Tropicales de México. Manual Para la Identificación de las Principales Especies; Universidad Nacional Autónoma de México: Mexico City, Mexico, 2005; ISBN 9789681678555.

24. White, D.A.; Hood, C.S. Vegetation patterns and environmental gradients in tropical dry forests of the northern Yucatan Peninsula. J. Veg. Sci. 2004, 15, 151-160. [CrossRef]

25. Williams-Linera, G.; Alvarez-Aquino, C.; Hernández-Ascención, E.; Toledo, M. Early successional sites and the recovery of vegetation structure and tree species of the tropical dry forest in Veracruz, Mexico. New For. 2011, 42, 131-148. [CrossRef]

26. López-Martínez, J.O.; Sanaphre-Villanueva, L.; Dupuy, J.M.; Hernández-Stefanoni, J.L.; Meave, J.A.; Gallardo-Cruz, J.A. $\beta$-Diversity of Functional Groups of Woody Plants in a Tropical Dry Forest in Yucatan. PLoS ONE 2013, 8, e73660. [CrossRef] [PubMed] 
27. Guariguata, M.R.; Ostertag, R. Neotropical secondary forest succession: Changes in structural and functional characteristics. For. Ecol. Manag. 2001, 148, 185-206. [CrossRef]

28. Chazdon, R.L. Tropical forest recovery: Legacies of human impact and natural disturbances. Perspect. Plant Ecol. Evol. Syst. 2003, 6, 51-71. [CrossRef]

29. Madeira, B.; Espírito-Santo, M.; Neto, S.; Nunes, Y.; Arturo Sánchez Azofeifa, G.; Wilson Fernandes, G.; Quesada, M. Changes in tree and liana communities along a successional gradient in a tropical dry forest in south-eastern Brazil. Plant Ecol. 2009, 201, 291-304. [CrossRef]

30. Cortés-Castelán, J.C.; Islebe, G.A. Influencia de factores ambientales en la distribución de especies arbóreas en las selvas del sureste de México. Rev. Biol. Trop. 2005, 53, 115-133.

31. Uhl, C. Factors Controlling Succession Following Slash-and-Burn Agriculture in Amazonia. J. Ecol. 1987, 75, 377-407. [CrossRef]

32. Organization for Economic Cooperation and Development; Food and Agriculture Organization of the United Nations. OECD-FAO Agricultural Outlook 2007; Food \& Agriculture Organization: Rome, Italy, 2007; ISBN 9789264025097.

33. Gisbert, J.; Ibáñez, S.; Moreno, H. La textura de un suelo. Available online: http://hdl.handle.net/10251/7775 (accessed on 5 December 2018).

34. Ceccon, E.; Huante, P.; Campo, J. Effects of nitrogen and phosphorus fertilization on the survival and recruitment of seedlings of dominant tree species in two abandoned tropical dry forests in Yucatán, Mexico. For. Ecol. Manag. 2003, 182, 387-402. [CrossRef]

35. Eaton, J.M.; Lawrence, D. Woody debris stocks and fluxes during succession in a dry tropical forest. For. Ecol. Manag. 2006, 232, 46-55. [CrossRef]

(C) 2019 by the authors. Licensee MDPI, Basel, Switzerland. This article is an open access article distributed under the terms and conditions of the Creative Commons Attribution (CC BY) license (http://creativecommons.org/licenses/by/4.0/). 